\title{
Cultivation under salt stress increases the concentration of recombinant miraculin in transgenic tomato fruit, resulting in an increase in purification efficiency
}

\author{
Tadayoshi Hirai, Narendra Duhita, Kyoko Hiwasa-Tanase, Hiroshi Ezura* \\ Gene Research Center, Graduate School of Life and Environmental Sciences, University of Tsukuba, Tsukuba, Ibaraki \\ 305-8572, Japan \\ *E-mail: ezura@gene.tsukuba.ac.jp Tel \& Fax: +81-29-853-7263
}

Received May 9, 2011; accepted July 26, 2011 (Edited by K. Hiratsuka)

\begin{abstract}
High target protein concentrations in source materials are important for achieving high purification efficiency. We sought to produce the taste-modifying protein, miraculin, in transgenic tomato fruits and then to extract and purify this protein. In order to improve the efficiency of recombinant miraculin purification from transgenic tomatoes, we tested a saltstress cultivation technique aimed at increasing miraculin concentration in the tomatoes. Two lines of transgenic tomatoes, $56 \mathrm{~B}$ and $5 \mathrm{~B}$, were grown under salt-stress conditions. There was a higher miraculin content per gram of fresh weight in transgenic tomatoes cultivated under salt stress than in tomatoes grown under non-stressed conditions. The observed increase in miraculin concentration was due to an enrichment effect caused by the miniaturization of tomatoes cultivated under salt stress. When the miraculin-enriched tomatoes were used for miraculin purification, the recovery rate of miraculin was higher.
\end{abstract}

Key words: Accumulation, miraculin, purification, salt stress, transgenic tomato.

Sweet-tasting proteins provide a potential benefit to human health because they can replace sucrose and help reduce caloric intake. Miraculin is unique in that, unlike brazzein (Ming and Hellekant 1994) or mabinlin (Liu et al. 1993), it is not a sweet-tasting protein but rather a taste modifier that can change sour tastes to sweet. Miraculin was originally discovered in the red berries of the miracle fruit (Richadella dulcifica), a shrub native to tropical western Africa (Kurihara and Beidler 1968). The 220-amino acid (aa) sequence of miraculin (Theerasilp et al. 1989) has been determined, and the 759 base pairs (bp) that code for miraculin cDNA have been cloned and sequenced (Masuda et al. 1995). Miraculin forms a homodimer with an apparent molecular weight of approximately $47 \mathrm{kDa}$ and localizes to the intercellular spaces in miracle fruit (Hirai et al. 2009). It accumulates only in the red berries of the miracle fruit and not in other parts of the plant. The miraculin concentration in the pericarp of red berries is approximately $400 \mu \mathrm{g} \mathrm{g}^{-1}$ of fresh weight (FW) (Kato et al. 2010), which is around $10 \%$ of the total soluble protein content (Theerasilp and Kurihara 1988).

Miracle fruit production is limited because it is a tropical plant. Several attempts have been made to introduce the miraculin gene into other organisms in order to produce the protein more efficiently. Recombinant miraculin can be produced in foreign hosts such as Escherichia coli (Kurihara 1992), yeast (Kurihara and Nirasawa 1997) and transgenic tobacco (Kurihara and Nirasawa 1997). Although miraculin has been expressed in these organisms, the recombinant miraculin protein obtained by these methods fails to exhibit taste-modifying activity. We have introduced the miraculin gene into other plants, such as lettuce (Sun et al. 2006), tomato (Sun et al. 2007), and strawberry (Sugaya et al. 2008). These three transgenic plants have been observed to accumulate recombinant miraculin protein with the highest accumulation level in transgenic tomato plants. The miraculin concentration in transgenic tomatoes is approximately $100 \mu \mathrm{g} \mathrm{g}^{-1} \mathrm{FW}$, which is $<1 \%$ of the total soluble protein content. In miraculinaccumulating transgenic tomatoes, the trait of miraculin accumulation is stably inherited, and it has been concluded that tomatoes are a suitable platform for the production of recombinant miraculin (Yano et al. 2010).

In order to use recombinant miraculin as a food additive and a chemical for research purposes, an efficient and effective purification method must be developed. We previously purified untagged miraculin from miraculin-accumulating tomatoes using a sequence 
of ammonium sulfate fractionation, ion-exchange chromatography, Con-A affinity chromatography, and Sephacryl S-200 HR column chromatography (Sun et al. 2007). However, this method is time-consuming and labor intensive. Therefore, we have developed a new rapid and simple miraculin purification method (Duhita et al. 2009; Duhita et al. 2011). This method involves using the His residues in the miraculin protein as a tag for nickel-immobilized affinity chromatography and ionexchange chromatography, which enables us to obtain highly purified and undenatured miraculin.

A high concentration of the target protein in the source material improves the recovery rate of miraculin during purification. Increasing the level of miraculin accumulation could improve the rate of recovery of recombinant miraculin from transgenic tomato fruit.

Many cultivation techniques are used around the world to cultivate tomatoes and produce high-quality fruit. Cultivation under salt stress using a hydroponic system, such as the nutrient film technique (NFT), was developed in Japan and northern Europe to produce high-quality tomato fruits (Adams 1991; Saito et al. 2008). Salt-stress conditions decrease the yield of tomatoes, producing a harvest with fewer, and smaller fruit (Adams and Ho 1989; Krauss et al. 2006; Saito et al. 2008; Willumsen et al. 1996). Several investigations have shown that salt stress enhances some qualities of tomato fruit, such as the sugar (De Pascale et al. 2001; Petersen et al. 1998; Yin et al. 2010), carotenoid (De Pascale et al. 2001; Krauss et al. 2006), total soluble protein (Krauss et al. 2006), and lycopene (Kubota et al. 2006) content. The greater content of these components are partly due to the enrichment effect associated with the decreased size of tomato fruit produced under salt stress. The relationship between the recombinant protein content and the cultivation of transgenic tomatoes under salt stress is unclear.

In this study, we report that salt-stress cultivation techniques are useful for increasing the miraculin concentration of transgenic tomato fruit, and we demonstrate that these miraculin-enriched tomato fruits have a higher rate of recovery of recombinant miraculin.

\section{Materials and methods}

\section{Miraculin-accumulating transgenic tomato}

The transgenic tomato lines 56B and 5B (upright type, cv. "Moneymaker"), which contain the miraculin gene (AB512278) driven by the CaMV 35S promoter-nos terminator cassette in the pBI121 vector and accumulate high concentrations of miraculin in the entire plant, have previously been produced and evaluated for their miraculin contents (Sun et al. 2007; Yano et al. 2010). The seeds of transgenic tomatoes and non-transgenic wild-type (WT) tomatoes were germinated on Petri dishes covered with moist filter paper at $25^{\circ} \mathrm{C}$ with a $16 \mathrm{~h}$ light $/ 8 \mathrm{~h}$ dark cycle. Seven days after sowing, the seedlings were transplanted to rock wool cubes $(5 \mathrm{~cm} \times 5 \mathrm{~cm} \times 5 \mathrm{~cm})$ and grown in a closed cultivation system (Nae Terasu) developed by Taiyo Kogyo Co., Ltd (Tokyo, Japan). This system supplies a nutrient solution to seedlings by using an ebb-and-flood system. The plants were grown at $25^{\circ} \mathrm{C} / 20^{\circ} \mathrm{C}$ (light/dark), with a daily cycle of $16 \mathrm{~h}$ of light provided by a fluorescent lamp at $450 \mu \mathrm{mol} \mathrm{m}^{-2} \mathrm{~s}^{-1}$ (PPF) and $8 \mathrm{~h}$ of darkness. Each day, the plants were provided with a nutrient solution that contained 565 $\mathrm{mg} \mathrm{L}^{-1} \mathrm{NO}_{3}^{-}, 15.7 \mathrm{mg} \mathrm{L}^{-1} \mathrm{NH}_{4}^{+}, 202.2 \mathrm{mg} \mathrm{L}^{-1} \mathrm{PO}_{3}^{-}, 218.4 \mathrm{mg} \mathrm{L}^{-1}$ $\mathrm{K}^{+}, 19.9 \mathrm{mg} \mathrm{L}^{-1} \mathrm{Mg}^{2+}, 95.0 \mathrm{mg} \mathrm{L}^{-1} \mathrm{Ca}^{2+}$ and micronutrients. After 30 days of growth in the "Nae terrace," the plants were transferred to a netted greenhouse.

\section{Cultivation under salt stress}

In the netted greenhouse, the tomato seedlings were watered using an NFT system. Otsuka-A nutrient solution, which was adjusted to an electrical conductivity (EC) of $2 \mathrm{dS} \mathrm{m}^{-1}$ (equivalent to $0 \mathrm{mM} \mathrm{NaCl}$ ), was used for watering until the anthesis of the first truss. After flowering, cultivation under salt stress was started. The EC of the nutrient solution was adjusted to 10 and $5 \mathrm{dS} \mathrm{m}^{-1}$ (equivalent to 100 and $50 \mathrm{mM} \mathrm{NaCl}$ ) by adding $\mathrm{NaCl}$ to the salt-stress medium, whereas the $\mathrm{EC}$ for the control medium was maintained at $2 \mathrm{dS} \mathrm{m}^{-1}$ until the time of harvest. After initiating the salt-stress conditions, the EC value was adjusted by the addition of Otsuka-A nutrient every week. The tomatoes were pruned, leaving three leaves above the third flower truss and maintaining five pieces of fruit per truss. The axillary buds were removed during the experiment. Sixty days after flowering, mature red fruit was harvested once every other day. The harvest was classified to separate marketable from unmarketable fruit (based on identification of blossom-end rot), and marketable fruit was weighed.

\section{Protein extraction, Western blot analysis and enzyme-linked immunosorbent assay}

Miraculin accumulation was determined by Western blot analysis and an enzyme-linked immunosorbent assay (ELISA). The harvested fruit was ground to a fine powder in liquid nitrogen, and $100 \mathrm{mg}$ of this powder was homogenized in 200 $\mu \mathrm{L}$ of an extraction buffer that consisted of $20 \mathrm{mM}$ Tris- $\mathrm{HCl}$ ( $\mathrm{pH} 8.0$ ), $500 \mathrm{mM} \mathrm{NaCl}$ and $2 \%$ polyvinylpolypyrrolidone (PVPP). The extracts were centrifuged at $15,000 \mathrm{rpm}$ for 20 $\min$ at $4{ }^{\circ} \mathrm{C}$, and the resulting supernatant was used for the immunoblot analyses and the ELISA. The extracted proteins (1 $\mathrm{mg}$ fresh weight equivalent per lane) were separated by sodium dodecyl sulfate polyacrylamide gel electrophoresis (SDSPAGE) and transferred onto Hybond-P polyvinylidene fluoride membranes (GE Healthcare Ltd., Amersham, Buckinghamshire, U.K.). The blots were incubated with affinity-purified antimiraculin antibody (Sun et al. 2007), followed by anti-rabbit immunoglobulin $\mathrm{G}(\mathrm{IgG})$ coupled to horseradish peroxidase. Immunoreactive signals were detected using a Peroxidase Stain Kit for Immunoblotting (Nacalai Tesque, INC. Kyoto, Japan), according to the manufacturer's instructions. The concentration of miraculin was determined by ELISA, as described by Kim et al. (2010). The protein concentrations of the extracts were determined using a BCA protein assay kit (Pierce). 
Purification of miraculin from miraculinaccumulating transgenic tomatoes

Miraculin was purified from the transgenic tomato line 5B. Five grams of the transgenic tomato fruit pericarps were ground into a fine powder using liquid nitrogen; this powder was homogenized in $20 \mathrm{ml}$ of distilled water to wash out soluble proteins and centrifuged at $12,000 \mathrm{rpm}$ for $20 \mathrm{~min}$. The supernatant was discarded, and the pellet was resuspended in an extraction buffer $(0.5 \mathrm{M} \mathrm{NaCl}, 20 \mathrm{mM}$ Tris-HCl, $\mathrm{pH}$ 7.2). After centrifugation at $12,000 \mathrm{rpm}$ for $20 \mathrm{~min}$, the supernatant was purified using a nickel-immobilized metal-affinity chromatography (IMAC) column (bet volume, $1 \mathrm{ml}$; HiTrap IMAC HP, GE Healthcare) and an ion exchange chromatography column (bet volume, $1 \mathrm{ml}$; HiTrap CM FF, GE Healthcare) as described by Narendra et al. (2011).

\section{Results and discussion}

\section{Quality of transgenic tomatoes cultivated under salt stress}

Salt stress resulted in fruit miniaturization and increased the Brix value and acidity (Cuartero and FernándezMuñoz 1994). An approximately $10 \%$ reduction in fruit weight occurred following irrigation with 4 to $5 \mathrm{dS} \mathrm{m}^{-1}$ water; a $30 \%$ reduction occurred with $8 \mathrm{dS} \mathrm{m}^{-1}$; and an approximately $40 \%$ reduction occurred at higher ECs (De Pascale et al. 2001; Gonzalez-Fernandez and
Cuartero 1993). The Brix value was observed to increase as a function of salt stress, to approximately 8 with an EC of $10 \mathrm{dS} \mathrm{m}^{-1}$ (Krauss et al. 2006; Saito et al. 2006).

In this study, the WT line and two lines of transgenic tomato that were grown under salt stress were observed to produce fruit. The sizes of the WT and transgenic fruit decreased as a function of increasing salt stress (Figure 1). The characteristics of the tomato fruit produced under salt stress are summarized in Table 1. Fruit weights and total fruit yields decreased as a function of salt stress in both the WT and the transgenic tomato lines; there were no significant differences in weight and total fruit yield between the WT and two transgenic tomato lines for all of the different salt-stress conditions investigated. Fruit weight decreased by approximately $10 \%$ with an EC of 5 $\mathrm{dS} \mathrm{m}^{-1}$, and by approximately $40 \%$ with an EC of $10 \mathrm{dS}$ $\mathrm{m}^{-1}$, compared to fruit grown at the control EC of $2 \mathrm{dS}$ $\mathrm{m}^{-1}$. These reductions are almost the same as those observed in previous reports (Saito et al. 2006). The total fruit yields of the WT and both transgenic tomato lines were remarkably decreased with EC $10 \mathrm{dS} \mathrm{m}^{-1}$ due to blossom-end rot. For the WT and both lines of transgenic tomatoes, the proportion of the cpericarp weight (exocarp and mesocarp) to the whole fruit weight was greatest when plants were cultivated with an EC of 5 $\mathrm{dS} \mathrm{m}^{-1}$.

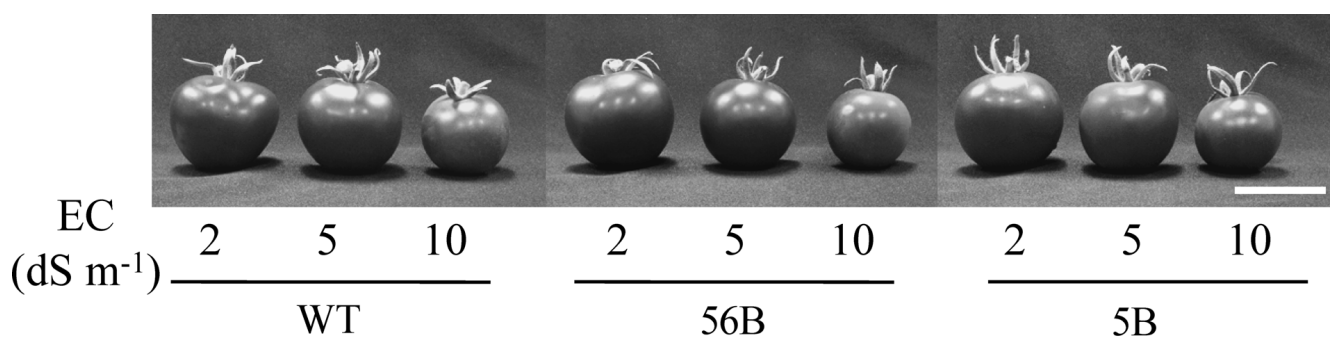

Figure 1. Fruit from the non-transgenic, wild-type (WT), line and miraculin-accumulating transgenic tomato lines (56B and 5B) grown under nonstressed condition (EC $2 \mathrm{dS} \mathrm{m}^{-1}$ ) and salt-stress conditions (EC 5 and $10 \mathrm{dS} \mathrm{m}^{-1}$ ). EC: electrical conductivity. Bar indicates $5 \mathrm{~cm}$.

Table 1. Fruit characteristics of non-transgenic wild-type (WT) tomatoes and miraculin-accumulating transgenic tomato lines 56B and 5B grown under non-stressed (EC $2 \mathrm{dS} \mathrm{m}^{-1}$ ) and salt-stress conditions (EC 5 and $10 \mathrm{dS} \mathrm{m}^{-1}$ ).

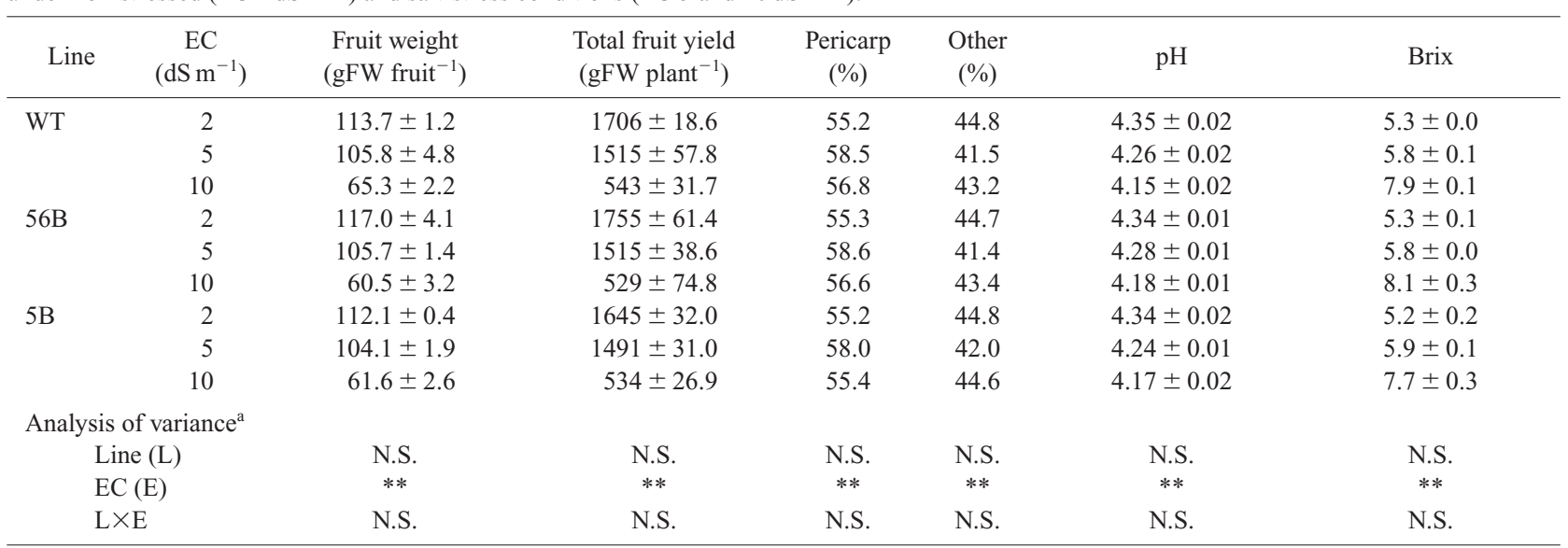

\footnotetext{
a ** and N.S. indicate significance at $p=0.01$ and not significant, respectively. EC, electrical conductivity; FW, fresh weight
} 
The $\mathrm{pH}$ inside each fruit decreased as a function of increasing salt stress, whereas the Brix value increased as a function of salt stress in the WT and both transgenic lines. There were no significant differences in pericarp weight ratio, $\mathrm{pH}$ or Brix values between the WT and either transgenic tomato line for any of the salt-stress conditions. To the best of our knowledge, the present study is the first to report the expression of a foreign gene by a transgenic tomato grown under salt stress.

In conclusion, these results demonstrate that salt stress affects the appearance and quality of the tomato fruit equally in WT and transgenic tomato lines.

\section{Miraculin concentration in transgenic fruit grown under salt-stress conditions}

Miraculin was detected in the fruit of 56B and 5B transgenic tomato plants that had been grown under the control condition and the salt stress conditions (Figure 2). The detected miraculin bands were broad because miraculin is a glycoprotein (Theerasilp and Kurihara, 1988). In Figure 2, the same amount of fruit matter (1.0 $\mathrm{mg}$ ) was used for all immunoblot analyses, and the miraculin bands for $56 \mathrm{~B}$ and $5 \mathrm{~B}$ tomatoes were more prominent at an EC of $10 \mathrm{dS} \mathrm{m}^{-1}$ than at lower EC conditions. The miraculin concentrations per FW and the concentrations of total soluble protein per FW in the fruit of the transgenic tomatoes that were grown under salt stress were estimated using an ELISA and a BCA protein assay, respectively. The results for the two lines of transgenic tomato grown under salt stress are presented in Table 2. The miraculin concentrations were highest for the transgenic tomato lines ( 282 and $304 \mu \mathrm{g} \mathrm{g}^{-1} \mathrm{FW}$ for $56 \mathrm{~B}$ and $5 \mathrm{~B}$, respectively) when they were grown with nutrient solution at an EC of $10 \mathrm{dS} \mathrm{m}^{-1}$. The total soluble protein content in the tomato fruit and the miraculin concentration per total soluble protein content differed

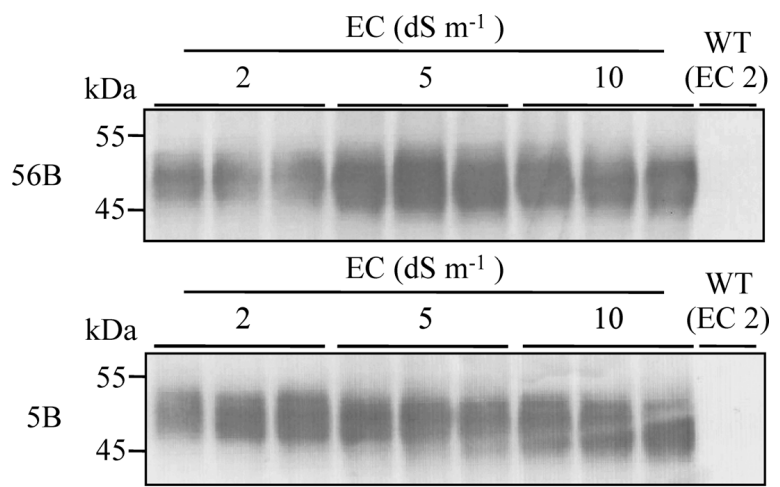

Figure 2. Accumulation of recombinant miraculin protein in the fruit of the transgenic tomato lines 56B and 5B grown under non-stressed (EC $2 \mathrm{dS} \mathrm{m}^{-1}$ ) and salt-stress conditions (EC 5 and $10 \mathrm{dS} \mathrm{m}^{-1}$ ). Recombinant miraculin was detected by Western blot analysis. One milligram fresh weight equivalent of tomato fruit grown under various salt-stress conditions was used for the Western blots. Three pieces of fruit were used for the analysis of each salt-stress condition. EC: electrical conductivity; WT: wild-type. slightly between the tomatoes grown at an EC of $2 \mathrm{dS}$ $\mathrm{m}^{-1}$ (control) and those grown at an EC of $5 \mathrm{dS} \mathrm{m}^{-1}$, whereas tomatoes grown at an EC of $10 \mathrm{dS} \mathrm{m}^{-1}$ had the highest miraculin concentrations in both lines $56 \mathrm{~B}$ and 5B. The miraculin concentration per total soluble protein content, which was estimated using the miraculin concentration per $\mathrm{FW}$ and the total soluble protein content per FW, did not differ significantly between the various salt-stress conditions investigated.

The contents of many of the components in tomato fruit, such as sugars, carotenoids, total soluble proteins,

Table 2. Miraculin concentration in transgenic tomato lines 56B and 5B grown under non-stressed (EC $2 \mathrm{dS} \mathrm{m}^{-1}$ ) and salt-stress conditions (EC 5 and $\left.10 \mathrm{dS} \mathrm{m}^{-1}\right)^{\mathrm{a}}$.

\begin{tabular}{|c|c|c|c|c|}
\hline Line & $\begin{array}{c}\mathrm{EC} \\
\left(\mathrm{dS} \mathrm{m}^{-1}\right)\end{array}$ & $\begin{array}{c}\mu \mathrm{g} \text { miraculin } \\
\mathrm{g}^{-1} \mathrm{FW}\end{array}$ & $\begin{array}{l}\text { mg protein } \\
\mathrm{g}^{-1} \mathrm{FW}\end{array}$ & $\begin{array}{l}\mu \mathrm{g} \text { miraculin } \\
\mathrm{mg}^{-1} \text { protein }\end{array}$ \\
\hline \multirow[t]{3}{*}{$56 \mathrm{~B}$} & 2 & $179.0 \pm 1.6$ & $20.4 \pm 0.3$ & $8.8 \pm 0.1$ \\
\hline & 5 & $186.5 \pm 21.0$ & $21.0 \pm 1.5$ & $9.0 \pm 1.2$ \\
\hline & 10 & $282.3 \pm 41.4$ & $28.3 \pm 0.8$ & $10.0 \pm 1.4$ \\
\hline \multirow[t]{3}{*}{$5 \mathrm{~B}$} & 2 & $172.2 \pm 22.3$ & $20.2 \pm 1.5$ & $8.5 \pm 0.5$ \\
\hline & 5 & $190.2 \pm 37.4$ & $21.2 \pm 0.3$ & $9.0 \pm 2.0$ \\
\hline & 10 & $304.1 \pm 32.1$ & $28.0 \pm 2.0$ & $10.8 \pm 0.6$ \\
\hline \multicolumn{5}{|c|}{$\begin{array}{l}\text { Analysis of } \\
\text { variance }^{\mathrm{b}}\end{array}$} \\
\hline \multicolumn{2}{|c|}{ Line (L) } & N.S. & N.S. & N.S. \\
\hline \multicolumn{2}{|c|}{$\mathrm{EC}(\mathrm{E})$} & $* *$ & $* *$ & N.S. \\
\hline \multicolumn{2}{|c|}{$\mathrm{L} \times \mathrm{E}$} & N.S. & N.S. & N.S. \\
\hline
\end{tabular}

${ }^{a}$ The miraculin concentrations in protein extracts obtained from the pericarps of the transgenic tomato lines $56 \mathrm{~B}$ and $5 \mathrm{~B}$ grown under nonstressed (EC $2 \mathrm{dS} \mathrm{m}^{-1}$ ) and salt-stress conditions (EC 5 and $10 \mathrm{dS} \mathrm{m}^{-1}$ ) were determined using an enzyme-linked immunosorbent assay (ELISA). Data represent the mean \pm standard error $(n=3)$. Total soluble protein concentrations were determined using a BCA Protein Assay Kit (Pierce, Rockford, IL, USA). ${ }^{\mathrm{b}} * *$ and N.S. indicate significance at $\mathrm{p}=0.01$ and not significant, respectively. EC, electrical conductivity; FW, fresh weight.

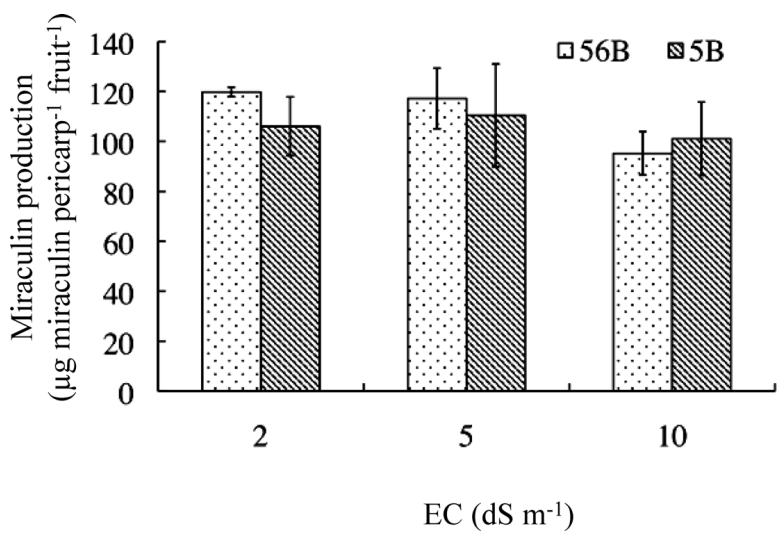

Figure 3. Miraculin production in the pericarps of miraculinaccumulating transgenic tomato fruit (lines 56B and 5B) grown under non-stressed (EC $2 \mathrm{dS} \mathrm{m}^{-1}$ ) and salt-stress conditions (EC 5 and $10 \mathrm{dS}$ $\mathrm{m}^{-1}$ ). Miraculin production was estimated from the fruit weight and proportion pericarp weight (\%) as shown in Table 1, and from the miraculin concentration as shown in Table 2. EC, electrical conductivity. 
Table 3. Miraculin purification and purified miraculin production from the pericarp of miraculin-accumulating tomatoes grown under non-stressed $\left(\text { EC } 2 \mathrm{dS} \mathrm{m}^{-1} \text { ) and salt-stress conditions (EC } 5 \text { and } 10 \mathrm{dS} \mathrm{m}^{-1}\right)^{\mathrm{a}}$.

\begin{tabular}{|c|c|c|c|c|c|c|c|}
\hline \multirow[b]{2}{*}{$\begin{array}{c}\mathrm{EC} \\
\left(\mathrm{dS} \mathrm{m}^{-1}\right)\end{array}$} & \multicolumn{2}{|c|}{ Before purification } & \multicolumn{2}{|c|}{ After purification } & \multirow[b]{2}{*}{$\begin{array}{c}\text { Recovery } \\
\text { rate }(\%)\end{array}$} & \multirow{2}{*}{$\begin{array}{l}\text { Purified miraculin } \\
\text { production } \\
\left(\mu \mathrm{g} \mathrm{miraculin}^{-1}\right. \\
\left.\text { pericarp }^{-1} \text { fruit }^{-1}\right)\end{array}$} & \multirow{2}{*}{$\begin{array}{c}\text { Purified miraculin } \\
\text { production } \\
(\mu \mathrm{g} \text { miraculin } \\
\left.\text { pericarp }^{-1} \text { plant }^{-1}\right)\end{array}$} \\
\hline & $\begin{array}{l}\text { Total soluble } \\
\text { protein } \\
\left(\mu \mathrm{g} \mathrm{ml}^{-1}\right)\end{array}$ & $\begin{array}{l}\text { Miraculin } \\
\left(\mu \mathrm{g} \mathrm{ml}^{-1}\right)\end{array}$ & $\begin{array}{l}\text { Total soluble } \\
\text { protein } \\
\left(\mu \mathrm{g} \mathrm{ml}^{-1}\right)\end{array}$ & $\begin{array}{l}\text { Miraculin } \\
\left(\mu \mathrm{g} \mathrm{ml}^{-1}\right)\end{array}$ & & & \\
\hline 2 & 111.7 & 47.5 & 11.9 & 11.8 & $25 \%$ & 21.9 & 321.1 \\
\hline 5 & 108.3 & 46.6 & 17.6 & 14.7 & $32 \%$ & 25.7 & 367.9 \\
\hline 10 & 144.0 & 45.3 & 21.1 & 17.6 & $39 \%$ & 17.4 & 150.4 \\
\hline
\end{tabular}

\footnotetext{
${ }^{\text {a }}$ The miraculin concentrations were determined using an enzyme-linked immunosorbent assay (ELISA). EC, electrical conductivity; FW, fresh
} weight.

and lycopene, were affected by salt stress (Neily et al. 2011; Saito et al. 2008). The observed enhancement of some of the aforementioned components was partly because of the enrichment associated with the miniaturization of fruit grown under salt stress. In this study, the miraculin content per FW and the total soluble protein content were increased by salt stress, whereas the miraculin concentration per total soluble protein content was the same under all salt-stress conditions. Therefore, the salt-stress-induced increase in miraculin content per FW was due to an increase in the total soluble protein content. If the increase in miraculin content per FW were due to the salt-stress-induced fruit miniaturization, miraculin production per fruit would not have changed as a result of salt stress. We estimated the average miraculin productivity in the pericarp using the pericarp weight and miraculin concentration per FW, as shown in Figure 3. Miraculin productivity did not vary significantly between the different salt-stress conditions or between the two transgenic lines. These results indicate that the enrichment in miraculin content per FW was a direct result of the fruit miniaturization effect caused by salt stress.

\section{Purification of miraculin from the transgenic tomato line $5 B$}

We intend to use miraculin-accumulating tomatoes as fresh fruit material and a source of miraculin to be used as a food additive and a research reagent. In order to use miraculin as a food additive and research reagent, we developed a procedure to purify recombinant miraculin from miraculin-accumulating tomatoes (Duhita et al. 2011). In general, the recovery rate of the purification process depends on the number of purification steps, the concentration of the target protein, and the concentration of inhibitors. In this study, recombinant miraculin was purified from miraculin-accumulating $5 \mathrm{~B}$ tomatoes grown under salt stress; these results are shown in Table 3. Prior to purification with a nickel column, the miraculin concentration was determined by ELISA using the supernatant collected after centrifugation during the extraction process. In this supernatant, the highest miraculin concentration was obtained from tomatoes grown at an $\mathrm{EC}$ of $2 \mathrm{dS} \mathrm{m}^{-1}$. This result was unexpected because the miraculin content per $\mathrm{FW}$ was higher in tomatoes grown at an $\mathrm{EC}$ of $10 \mathrm{dS} \mathrm{m}^{-1}$. We believe that the decreased miraculin concentration recovered from fruit grown at an $\mathrm{EC}$ of $10 \mathrm{dS} \mathrm{m}^{-1}$ was caused by protein precipitation due to changes in specific characteristics, such as increased sugar and organic acid content, influenced by salt stress. After purification, the miraculin concentration recovered was highest from fruit grown at an EC of $10 \mathrm{dS} \mathrm{m}^{-1}$. The recovery rate was calculated by comparing the miraculin concentration in the sample before and after extraction, and it was highest for fruit cultivated at an EC of $10 \mathrm{dS} \mathrm{m}^{-1}$, even though the miraculin concentration before purification was lowest at an EC of $10 \mathrm{dS} \mathrm{m}^{-1}$. This high recovery rate from tomatoes grown at an $\mathrm{EC}$ of $10 \mathrm{dS} \mathrm{m}^{-1}$ might be the result of a decrease in a substance that inhibits the binding of miraculin to the IMAC column in fruit grown under salt stress. The recovery of purified miraculin per fruit and per plant was estimated based on the purification recovery rate (Table 3), the miraculin concentration per FW of pericarp (Table 2), the pericarp weight (Table 1) and the total fruit yield (Table 1). The productivity of purified miraculin per fruit and per plant was highest for fruit grown at an EC of $5 \mathrm{dS} \mathrm{m}^{-1}$. The higher productivity was found to result from the higher fruit weight and total fruit yield observed at an EC of 5 $\mathrm{dS} \mathrm{m}^{-1}$ compared to an EC of 10, the higher miraculin concentration at an EC of $5 \mathrm{dS} \mathrm{m}^{-1}$ compared to an EC of 2 , and the intermediate recovery ratio.

In this study, we cultivated miraculin-accumulating transgenic tomatoes under salt-stress conditions and demonstrated that the miraculin concentration per FW was increased by salt stress. We also determined that the enhancement in miraculin concentration was caused by the enrichment effect of salt-stress-induced tomato fruit miniaturization, and we demonstrated that highly purified miraculin protein can be extracted from miraculin-enriched transgenic tomatoes. The results presented in this study will direct the future use of recombinant miraculin and future studies involving recombinant protein expression in transgenic tomatoes. 


\section{Acknowledgements}

We thank the members of the Ezura laboratory for helpful discussions. "Moneymaker" seeds (TOMJPF00002) were obtained from the National BioResource Project Tomato (NBRP-tomato). This research was supported by the "Development of Fundamental Technologies for the Production of High-Value Materials Using Transgenic Plants" project of the Ministry of Economy, Trade, and Industry of Japan (to H.E.).

\section{References}

Adams P, Ho KC (1989) Effects of constant and fluctuatin salinity on the yield, quality and calcium status of tomatoes. J Hort Sci 64: 725-732

Adams P (1991) Effects of increasing the salinity of the nutrient solution with major nutrients or sodium chloride on the yield, quality and composition of tomatoes grown in rockwool. $J$ Hort Sci 66: 201-207

Cuartero J, Fernández-Muñoz R (1994) Tomato and salinity. Sci Hortic 78: 83-125

De Pascale S, Maggio A, Fogliano V, Ambrosino P, Ritieni A (2001) Irrigation with saline water improves carotenoids content and antioxidant activity of tomato. J Hortic Sci Biotechnol 76: $447-453$

Duhita N, Hiwasa-Tanase K, Yoshida S, Ezura H (2009) Singlestep purification of native miraculin using immobilized metal affinity chromatography. J Agric Food Chem 57: 5148-5151

Duhita N, Hiwasa-Tanase K, Yoshida S, Ezura H (2011) A simple method for purifying undenatured miraculin from transgenic tomato fruit. Plant Biotechnol 28: 281-286

Gonzalez-Fernandez JJ, Cuartero J (1993) Evolucion de la produccion de cuatro entradas de tomate cultivadas con sal. Actas de Horticultura 10: 1067-1072

Hirai T, Sato M, Toyooka K, Sun HJ, Yano M, Ezura H (2009) Miraculin, a taste-modifying protein is secreted into intercellular spaces in plant cells. J Plant Physiol 167: 209-215

Kato K, Yoshida R, Kikuzaki A, Hirai T, Kuroda H, Hiwasa-Tanase K, Takane K, Ezura H, Mizoguchi T (2010) Molecular breeding of tomato lines for mass production of miraculin in a plant factory. J Agric Food Chem 58: 9505-9510

Kim YW, Kato K, Hirai T, Hiwasa-Tanase K, Ezura H (2010) Spatial and developmental profiling of miraculin accumulation in transgenic tomato fruits expressing the miraculin gene constitutively. J Agri Food Chem 58: 282-286

Krauss S, Schnitzler WH, Grassmann J, Woitke M (2006) The influence of different electrical conductivity values in a simplified recirculating soilless system on inner and outer fruit quality characteristics of tomato. J Agric Food Chem 54: 441448

Kubota C, Thomson CA, Min W, Javanmardi J (2006) Controlled environments for production of value-added food crop with high pytochemical concentrations: lycopene in tomato as an example HortScience 41: 522-525

Kurihara K, Beidler LM (1968) Taste-modifying protein from miracle fruit. Science 161: 1241-1243

Kurihara Y (1992) Characteristics of antisweet substances, sweet proteins, and sweetness-inducing proteins. Crit Rev Food Sci Nutr 32: 231-252

Kurihara Y, Nirasawa S (1997) Structures and activities of sweetness-inducing substances (miraculin, curculin, strogin) and the heat-stable sweet protein, mabinlin. FFI J Jpn 174: 67-74

Liu X, Maeda S, Hu Z, Aiuchi T, Nakaya K, Kurihara Y (1993) Purification, complete amino acid sequence and structure characterization of the heat stable protein, mabinlin II. Eur J Biochem 211: 281-287

Masuda Y, Nirasawa S, Nakaya K, Kurihara Y (1995) Cloning and sequencing of a cDNA encoding a taste-modifying protein, miraculin. Gene 161: 175-177

Ming D, Hellekant G (1994) Brazzein, a new high-potency thermostable sweet protein from Pentadiplandra brazzeana B. FEBS Lett 355: 106-108

Neily MH, Matsukura C, Mickael M, Bernillon S, Deborde C, Moing A, Yin YG, Saito T, Mori K, Asamizu E, Rolin D, Moriguchi T, Ezura H (2011) Enhanced polyamine accumulation alters carotenoid metabolism at the transcriptional level in tomato fruit over-expressing spermidine synthase. $J$ Plant Physiol 168: 242-252

Petersen K, Willumsen J, Kaack K (1998) Composition and taste of tomatoes as affected by increased salinity and different salinity sources. J Hortic Sci Biotechnol 73: 205-215

Saito T, Fukuda N, Nishimura S (2006) Effects of salinity treatment duration and planting density on size and sugar content of hydroponically grown tomato fruits. J Jpn Soc Hort Sci 75: 392-398

Saito T, Matsukura C, Ban Y, Shoji K, Sugiyama M, Fukuda N, Nishimura S (2008) Salinity stress affects assimilate metabolism at the gene-expression level during fruit development and improves fruit quality in tomato (Solanum lycopersicum L.). $J$ Jpn Soc Hort Sci 77: 61-68.

Sugaya T, Yano M, Sun HJ, Hirai T, Ezura H (2008) Transgenic strawberry expressing the taste-modifying protein miraculin. Plant Biotechnol 25: 329-333

Sun HJ, Cui ML, Ma B, Ezura H (2006) Functional expression of the taste-modifying protein, miraculin, in transgenic lettuce. FEBS Lett 508: 620-626

Sun HJ, Kataoka H, Yano M, Ezura H (2007) Genetically stable expression of functional miraculin, a new type of alternative sweetener, in transgenic tomato plants. Plant Biotechnol $J$ 5: 768-777

Theerasilp S, Kurihara Y (1988) Complete purification and charac terization of the taste-modifying protein, miraculin, from miracle fruit. J Biol Chem 263: 11536-11539

Theerasilp S, Hitotsuya H, Nakajo S, Nakaya K, Nakamura Y, Kurihara Y (1989) Complete amino acid sequence and structure characterization of the taste-modifying protein, miraculin. $J$ Biol Chem 264: 6655-6659

Willumsen J, Petersen KK, Kaack K (1996) Yield and blossom-end rot of tomato affected by salinity and cation activity ratios in the root zone. J Hort Sci 71: 81-98

Yano M, Hirai T, Kato K, Hiwasa-Tanase K, Fukuda N, Ezura H (2010) Tomato is a suitable material for producing recombinant miraculin protein in genetically stable manner. Plant Sci 178: 469-473

Yin YG, Kobatyashi Y, Sanuki A, Kondo S, Fukuda N, Ezura H, Sugaya S, Matsukura C (2010) Salinity induces carbohydrate accumulation and sugar-regulated starch biosynthetic genes in tomato (Solanum lycopersicum L. cv. "Micro-Tom") fruits in an ABA- and osmotic stress-independent manner. J Exp Bot 61: $563-574$ 